\title{
KONTRIBUSI VIRTUAL LABORATORY \\ PADA PEMBELAJARAN TITRASI ASAM-BASA DENGAN \\ PREDICT-OBSERVE-EXPLAIN TERHADAP HASIL BELAJAR DAN KETERAMPILAN BERPIKIR KRITIS
}

\author{
Hanifah Kartika $\mathbf{S}^{1}$, Harjono ${ }^{2}$, Woro Sumarni ${ }^{3}$, Murbangun $\mathbf{N}^{4}$ \\ 1,2,3,4 Jurusan Kimia FMIPA Universitas Negeri Semarang
}

Jl. Raya Sekaran, Sekaran, Kec. Gunungpati, Kota Semarang, Jawa Tengah 50229

\begin{abstract}
Abstrak
Penelitian ini bertujuan untuk mengetahui kontribusi media virtual laboratory dalam model pembelajaran Predict-Observe-Explain (POE) terhadap hasil belajar dan keterampilan berpikir kritis peserta didik pada materi titrasi asam-basa. Penelitian menggunakan desain quasi experimental dengan pretest-posttest control group design yang dilaksanakan di SMA Negeri 12 Semarang. Objek penelitian adalah peserta didik kelas XI IPA 3 sebagai kelas kontrol dan XI IPA 5 sebagai kelas eksperimen. Pada kelas eksperimen dilakukan pembelajaran dengan model POE disertai demonstrasi dan pemanfaatan virtual laboratory, sedangkan pada kelas kontrol dilakukan pembelajaran dengan model POE disertai demonstrasi. Kedua kelas kemudian melakukan praktikum. Pengamatan dan analisis dilakukan pada hasil belajar yang terdiri dari 3 aspek yaitu aspek kognitif, afektif, dan psikomotorik, dan Keterampilan Berpikir Kritis (KBK) dari kedua kelas tersebut. Hasil penelitian menunjukkan terdapat perbedaan rata-rata hasil belajar dan keterampilan berpikir kritis antara kelas eksperimen dan kelas kontrol pada pembelajaran POE berbantuan virtual laboratory. Kontribusi virtual laboratory terhadap hasil belajar sebesar 16,99\%, sedangkan kontribusi virtual laboratory terhadap keterampilan berpikir kritis sebesar $12,66 \%$.
\end{abstract}

Kata kunci: hasil belajar, keterampilan berpikir kritis, model PredictObserve-Explain, virtual laboratory

Universitas Negeri Semarang

Email: hanifahkartika620@gmail.com
(C)2019 Universitas Islam Negeri Walisongo 190

ISSN: 2088-7868, e-ISSN 2502-5708 


\begin{abstract}
This study aims to determine the contribution of virtual laboratory media in the Predict-Observe-Explain (POE) learning model towards learning outcomes and students' critical thinking skills on acid-base titration material. The study used a quasi experimental design with pretest-posttest control group design which was carried out at SMA Negeri 12 Semarang. The object of research is students of class XI IPA 3 as a control class and XI IPA 5 as an experimental class. In the experimental class learning is done with the POE model accompanied by demonstrations and the use of virtual laboratories, while in the control class learning is carried out with the POE model accompanied by demonstrations. Both classes then do the practicum. Observations and analyzes were carried out on learning outcomes consisting of 3 aspects namely cognitive, affective, and psychomotor aspects, and Critical Thinking Skills (CBC) of the two classes. The results showed that there were differences in the average learning outcomes and critical thinking skills between the experimental class and the control class in POE-assisted virtual laboratory learning. The contribution of the virtual laboratory to learning outcomes was $16.99 \%$, while the contribution of the virtual laboratory to critical thinking skills was $12.66 \%$.
\end{abstract}

Keywords: learning outcomes, critical thinking skills, Predict-ObserveExplain model, virtual laboratory

\title{
PENDAHULUAN
}

Tantangan pendidikan selain tuntutan kurikulum 2013 saat ini adalah mengembangkan keterampilan abad 21 yang terdiri dari keterampilan teknologi informasi dan komunikasi (information \& communication technology literacy skill), keterampilan berpikir kritis (critical thinking skill), keterampilan memecahkan masalah (problem solving skill), keterampilan berkomunikasi efektif (effective communication skill) dan keterampilan berkolaborasi (collaborate skill) (Yusuf \& Widyaningsih, 2017). Pada saat ini perlu diadakan inovasi pembelajaran agar dapat memanfaatkan teknologi dengan maksimal dan dapat melatih keterampilan berpikir kritis dan meningkatkan hasil belajar peserta didik, khususnya pada pelajaran Kimia.

Kimia merupakan cabang dari Ilmu Pengetahuan Alam (IPA) yang memiliki peran penting dalam perkembangan ilmu pengetahuan. Oleh karena itu, peserta didik dituntut untuk menguasai materi Kimia secara mendalam. Cara yang dilakukan untuk mencapai hal tersebut yaitu guru harus kreatif dalam memilih media pembelajaran yang tepat. Keberhasilan proses pembelajaran dipengaruhi oleh penggunaan media yang sesuai dengan tujuan yang akan dicapai. Media pembelajaran yang baik yaitu media yang menggunakan teknologi untuk mengakses informasi yang diperlukan peserta didik 
baik dari guru, teman sebaya, dan aplikasi perangkat (Fabian et al., 2016).

Observasi awal dilakukan di SMA Negeri 12 Semarang untuk mengetahui proses pembelajaran Kimia dengan teknik wawancara. Hasil wawancara menunjukkan bahwa pelaksanaan praktikum di sekolah hanya dilakukan melalui praktikum riil dan belum pernah menggunakan virtual laboratory. Peserta didik banyak yang belum terampil ketika melaksanakan praktikum riil sehingga banyak yang sering bertanya kepada guru saat praktikum berlangsung dan mengakibatkan praktikum menjadi terhambat. Selain itu peserta didik dalam melakukan kegiatan praktikum tidak diminta untuk memprediksi hasil praktikum terlebih dahulu akan tetapi langsung melakukan praktikum sesuai dengan panduan yang disediakan. Peserta didik selanjutnya diminta untuk membuat laporan praktikum kemudian dikumpulkan kepada guru Kimia.

Selain wawancara juga dilakukan studi literatur mengenai hasil belajar dan keterampilan berpikir kritis peserta didik. Hasil belajar peserta didik khususnya pada materi titrasi asam-basa juga masih tergolong rendah. Pembelajaran seperti ini dapat membuat peserta didik kehilangan semangat untuk belajar, memberikan dampak negatif pada peserta didik dan menurunnya mutu pendidikan di sekolah. Hal ini sesuai penelitian Rosa \& Nursa'adah (2017), kurangnya respon peserta didik terhadap pemanfaatan laboratorium Kimia juga menyebabkan rendahnya keterampilan berpikir kritis pada pelajaran Kimia. Selain itu Bakhtiar (2016) dalam penelitiannya mengungkapkan bahwa peserta didik bersikap pasif, tidak terlibat mengajukan pertanyaan, mengemukakan pendapat/gagasan maupun memberikan sanggahan terhadap suatu pendapat/gagasan. Beberapa permasalahan lain yang menyebabkan rendahnya keterampilan berpikir kritis peserta didik yaitu ilmu Kimia banyak memiliki konsep abstrak sehingga Kimia cenderung tidak disukai dan sulit dipahami. Oleh karena itu, perlu adanya pemilihan media yang menarik dan model pembelajaran yang sesuai agar peserta didik memiliki hasil belajar yang baik dan dapat melatih keterampilan berpikir kritis dalam proses pembelajaran.

Proses pembelajaran yang baik dapat diperoleh dengan menggunakan media yang menarik. Pembelajaran yang dikemas secara menarik diharapkan mampu memberikan suasana pembelajaran yang berbeda dan membekas bagi peserta didik tetapi yang paling utama adalah membantu peserta didik memahami materi kimia (Argandi et al., 2013). Virtual laboratory merupakan salah satu alternatif media yang menarik bagi peserta 
didik dalam belajar Kimia. Penggunaan virtual laboratory merupakan hal yang baru bagi peserta didik sehingga diharapkan dapat menarik perhatian peserta didik untuk belajar Kimia dengan baik dan peserta didik menjadi lebih terampil dalam melakukan praktikum. Virtual laboratory juga telah terbukti dapat meningkatkan motivasi belajar peserta didik (Ikhsan \& Afdal, 2016) dan keterampilan berpikir kritis (Permana et al., 2016). Media yang menarik harus diselaraskan dengan penggunaan model pembelajaran yang sesuai, salah satunya yaitu model pembelajaran POE.

Model pembelajaran POE (Predict-Observe-Explain) sering digunakan dalam pengajaran sains. POE membutuhkan tiga kegiatan. Pertama, membantu untuk mengungkapkan prediksi masing-masing peserta didik tentang peristiwa tertentu. Kedua, peserta didik menggambarkan apa yang dilihat dalam proses pengamatan. Ketiga, peserta didik harus menjelaskan hasil pengamatan dari proses pengamatan yang dilakukan. Peserta didik dapat mengetahui kebenaran dari prediksi yang telah mereka buat sebelum melakukan pengamatan dengan hasil pengamatan yang diperoleh (Srereekha, 2016). POE merupakan cara yang efektif dan dapat memungkinkan peserta didik untuk belajar melalui pengalaman, menjadikan peserta didik lebih aktif dan dapat menemukan kebenaran dari suatu hipotesis berdasarkan praktikum yang dilakukan (Ayvaci, 2013). POE juga terbukti dapat meningkatkan minat belajar dan hasil belajar peserta didik (Erni et al., 2013).

Pembelajaran POE berbantuan virtual laboratory diharapkan dapat menjadikan peserta didik lebih berani untuk melakukan praktikum-praktikum tanpa rasa cemas terhadap keselamatan diri. Peserta didik dapat mengeksplor pengetahuan dengan mencoba praktikum-praktikum baru dan memprediksikan hasil yang akan diperoleh tanpa khawatir bahan-bahan habis dan alat-alat rusak. Virtual laboratory juga dapat menambah literasi di bidang TIK, meningkatkan hasil belajar, dan melatih keterampilan berpikir kritis.

Pada penelitian ini kelas eksperimen diberi pembelajaran POE berbantuan virtual laboratory pokok materi titrasi asam-basa sedangkan kelas kontrol tanpa bantuan virtual laboratory. Peneliti ingin mengetahui kontribusi virtual laboratory pada pembelajaran titrasi asam-basa dengan predict-observe-explain terhadap hasil belajar dan keterampilan berpikir kritis. 


\section{METODE PENELITIAN}

Penelitian ini menggunakan desain quasi experimental dengan pretest-posttest control group design yang dilaksanakan di SMA Negeri 12 Semarang pada bulan Februari 2019. Populasi penelitian adalah peserta didik kelas XI IPA dengan sampel peserta didik kelas XI IPA 3 sebagai kelas kontrol dan XI IPA 5 sebagai kelas eksperimen. Perlakuan untuk kelas eksperimen yaitu pembelajaran dengan model POE dan pemanfaatan virtual laboratory disertai demonstrasi pada pokok materi titrasi asambasa, sedangkan pada kelas kontrol pembelajaran dilakuan dengan model POE dan hanya disertai demonstrasi titrasi asam-basa tanpa bantuan virtual laboratory. Kelas eksperimen dan kelas kontrol kemudian melakukan praktikum riil di laboratorium Kimia. Instrumen yang digunakan dalam penelitian ini yaitu soal tes pilihan ganda two tier dan lembar observasi. Teknik pengumpulan data dilakukan dengan tes dan observasi. Hasil belajar kognitif dan keterampilan berpikir kritis dilakukan analisis dengan uji normalitas, uji kesamaan varians, uji dua rata-rata (satu pihak), uji pengaruh antar variabel, dan penentuan koefisien determinasi. Hasil belajar aspek afektif dan psikomotorik dilakukan analisis deskriptif.

\section{HASIL DAN PEMBAHASAN}

Penelitian ini merupakan quasi experimental dengan mengukur hasil belajar aspek kognitif, observasi hasil belajar aspek afektif dan psikomotorik serta pengukuran keterampilan berpikir kritis. Data-data yang diperoleh selanjutnya dianalisis menggunakan teknik analisis data yang sesuai. Hasil belajar aspek kognitif diukur dengan instrumen tes pilihan ganda two tier melalui pretest dan posttest. Nilai pretest diperoleh data berdistribusi normal, memiliki varians dan rata-rata yang sama antara kedua kelas eksperimen dan kontrol. Nilai posttest yang diperoleh dilakukan beberapa analisis yaitu uji normalitas, uji varians, uji dua rata-rata (satu pihak), uji pengaruh, dan penghitungan koefisien determinasi. Hasil uji normalitas nilai posttest dari kedua kelompok yaitu berdistribusi normal. Hasil uji kesamaan varians diperoleh nilai $\mathrm{F}$ hitung sebesar 2,596 dan F tabel sebesar 2,120. F hitung lebih besar dari F tabel. Hal ini menunjukkan bahwa nilai posttest kelompok kontrol dan eksperimen memiliki varians yang berbeda (Ho ditolak) sehingga uji dua rata-rata (satu pihak) dilakukan dengan menggunakan rumus t'. Hasil uji dua rata-rata (satu pihak) diperoleh nilai t' hitung 
sebesar 2,59 dan nilai t tabel sebesar 1,70. Nilai t' hitung lebih besar dari t tabel. Hasil tersebut menunjukkan bahwa rata-rata nilai posttest kelas eksperimen lebih besar dari kelas kontrol. Hasil uji pengaruh antar variabel menghasilkan koefisien korelasi biserial sebesar 0,41 dan masuk dalam kategori sedang. Penghitungan koefisien determinasi menghasilkan persen kontribusi virtual laboratory terhadap hasil belajar peserta didik sebesar 16,99\%. Hasil ini memperlihatkan bahwa virtual laboratory berkontribusi terhadap hasil belajar aspek kognitif peserta didik.

Peserta didik yang menggunakan virtual laboratory lebih banyak menghasilkan jawaban benar (Harrison, 2009 dalam Tatli \& Ayas, 2010). Hasil penelitian Hikmah, dkk (2017) menyatakan bahwa penilaian akhir didapatkan nilai rata-rata pada kelas eksperimen lebih unggul dari nilai rata-rata kelas kontrol pada penerapan laboratorium virtual. Virtual laboratory pada kelas eksperimen menjadikan peserta didik memiliki pemahaman konsep yang baik (Rizkiana et al., 2018) dan menambah motivasi belajar peserta didik (Rizkiana et al., 2018 dan Ikhsan \& Afdal, 2016) sehingga menghasilkan nilai rata-rata yang lebih baik daripada kelas kontrol. Penelitian Argandi, dkk (2013) dan Matsun dkk (2016) menyatakan bahwa prestasi belajar aspek kognitif pada peserta didik yang diajar berbantuan kegiatan laboratorium virtual lebih baik daripada tanpa laboratorium virtual. Mulyatun (2013) menyatakan bahwa hasil belajar Kimia yang menggunakan laboratorium Kimia virtual lebih baik daripada hasil belajar Kimia yang tidak menggunakan laboratorium Kimia virtual. Jaya (2012) menyatakan bahwa laboratorium virtual dapat meningkatkan kompetensi peserta didik dari segi kognitif.

Hasil penelitian yang diperoleh berikutnya yaitu hasil belajar aspek afektif. Hasil belajar aspek afektif diperoleh melalui observasi selama proses pembelajaran berlangsung. Hasil observasi aspek afektif peserta didik disajikan pada Tabel 1.

Berdasarkan data pada Tabel 1 hasil belajar aspek afektif kelas eksperimen lebih baik daripada kelas kontrol. Pada kelas eksperimen terdapat 28 peserta didik memenuhi kriteria sangat baik dan 2 peserta didik memenuhi kriteria baik. Pada kelas kontrol terdapat masing-masing 13 peserta didik memenuhi kriteria sangat baik dan 15 peserta didik memenuhi kriteria baik. Aspek afektif dalam penelitian ini terdapat 7 kategori yang diamati yaitu jujur, disiplin, rasa ingin tahu, tanggungjawab, kerjasama, santun, dan percaya diri. Rata-rata skor masing-masing kategori disajikan pada Tabel 2.

Berdasarkan data pada Tabel 2, terdapat 6 indikator aspek afektif kelas 
eksperimen yang lebih tinggi daripada kelas kontrol. Enam indikator tersebut yaitu jujur, disiplin, rasa ingin tahu, tanggungjawab, santun, dan percaya diri. Tidak semua aspek sikap kelas eksperimen lebih tinggi daripada kelas kontrol. Pada aspek kerjasama, kelas kontrol memiliki rata-rata skor yang lebih tinggi daripada kelas eksperimen. Hal ini disebabkan karena peserta didik pada kelas eksperimen sudah lebih mengetahui proses praktikum yang mereka laksanakan karena telah didahului praktikum menggunakan virtual laboratory sehingga masing-masing peserta didik cenderung fokus dengan pekerjaannya. Pada kelas kontrol, peserta didik cenderung lebih sering bertanya dan bekerjasama dengan temannya karena belum memahami penuh tentang praktikum titrasi asam-basa yang merupakan praktikum titrasi yang pertama dilakukan.

Tabel 1 Hasil Observasi Aspek Afektif

\begin{tabular}{|c|c|c|c|c|c|}
\hline \multirow[b]{2}{*}{ Kelas } & \multicolumn{4}{|c|}{ Kategori } & \multirow{2}{*}{$\begin{array}{c}\text { Jumlah } \\
\text { Peserta Didik }\end{array}$} \\
\hline & $\begin{array}{c}\text { Sangat Baik } \\
\text { (A) }\end{array}$ & $\begin{array}{l}\text { Baik } \\
\text { (B) }\end{array}$ & $\begin{array}{l}\text { Cukup } \\
\text { (C) }\end{array}$ & $\begin{array}{l}\text { Kurang } \\
\text { (D) }\end{array}$ & \\
\hline Kontrol & 13 & 15 & 0 & 0 & 28 \\
\hline Eksperimen & 28 & 2 & 0 & 0 & 30 \\
\hline
\end{tabular}

Tabel 2 Rata-rata Skor Aspek Afektif

\begin{tabular}{clcc}
\hline \multirow{2}{*}{ No. } & \multicolumn{2}{|}{ Aspek Afektif } & \multicolumn{2}{c}{ Rata-rata Skor } \\
\cline { 3 - 4 } & & Kelas Kontrol & Kelas Eksperimen \\
\hline 1. & Jujur & 3,38 & 3,62 \\
2. & Disiplin & 3,64 & 3,69 \\
3. & Rasa ingin tahu & 1,77 & 2,49 \\
4. & Tanggungjawab & 3,80 & 3,87 \\
5. & Kerjasama & 3,68 & 3,47 \\
6. & Santun & 3,54 & 3,91 \\
7. & Percaya diri & 1,52 & 2,30 \\
\hline
\end{tabular}

Berdasarkan data pada Tabel 2, hasil belajar aspek afektif kelas eksperimen lebih tinggi daripada kelas kontrol atau kelas yang menggunakan bantuan virtual laboratory memiliki rata-rata hasil belajar aspek afektif yang lebih tinggi daripada kelas tanpa bantuan virtual laboratory. Hasil ini sejalan dengan penelitian Argandi, dkk (2013) dan Matsun, dkk (2016) yang menyatakan bahwa prestasi belajar aspek afektif pada peserta didik yang belajar berbantuan kegiatan laboratorium virtual lebih baik daripada tanpa laboratorium virtual. Penelitian Surbakti dan Supartono (2016) pembelajaran berbasis TIK dapat menanamkan nilai-nilai karakter peserta didik. Penelitian Jaya (2012) 
menyatakan bahwa laboratorium virtual dapat memfasilitasi pendidikan karakter peserta didik.

Hasil penelitian yang diperoleh selanjutnya yaitu hasil belajar aspek psikomotorik. Hasil belajar aspek psikomotorik diperoleh melalui observasi saat peserta didik melakukan praktikum titrasi asam-basa di laboratorium Kimia. Hasil observasi aspek psikomotorik peserta didik disajikan pada Tabel 3.

Berdasarkan data pada Tabel 3 diperoleh bahwa hasil belajar aspek psikomotorik kelas eksperimen lebih baik daripada kelas kontrol. Pada kelas eksperimen 30 peserta didik memenuhi kriteria sangat baik, sedangkan pada kelas kontrol terdapat 27 peserta didik memenuhi kriteria sangat baik dan 1 peserta didik memenuhi kriteria baik.

Observasi aspek psikomotorik dalam penelitian ini terdapat 3 kategori yang diamati yaitu kegiatan awal praktikum, kegiatan praktikum, dan kegiatan akhir praktikum, hasil lengkap ditunjukkan pada Tabel 4. Kegiatan awal praktikum terdiri dari perencanaan/perancangan kegiatan dan persiapan alat dan bahan. Kegiatan praktikum terdiri dari mengatur alat dan bahan, mengamati titik akhir titrasi, dan menyimpulkan hasil praktikum. Kegiatan akhir praktikum terdiri dari perlakuan terhadap alat dan kebersihan tempat kerja.

Tabel 3 Hasil Observasi Aspek Psikomotorik

\begin{tabular}{|c|c|c|c|c|c|}
\hline \multirow[b]{2}{*}{ Kelas } & \multicolumn{4}{|c|}{ Kategori } & \multirow[b]{2}{*}{$\begin{array}{c}\text { Jumlah Peserta } \\
\text { Didik }\end{array}$} \\
\hline & $\begin{array}{l}\text { Sangat Tinggi } \\
\text { (A) }\end{array}$ & $\begin{array}{l}\text { Tinggi } \\
\text { (B) }\end{array}$ & $\begin{array}{l}\text { Cukup } \\
\text { (C) }\end{array}$ & $\begin{array}{l}\text { Kurang } \\
\text { (D) }\end{array}$ & \\
\hline Kontrol & 27 & 1 & 0 & 0 & 28 \\
\hline Eksperimen & 30 & 0 & 0 & 0 & 30 \\
\hline
\end{tabular}

Tabel 4 Rata-rata Skor Indikator Aspek Psikomotorik

\begin{tabular}{clcc}
\hline \multirow{2}{*}{ No. } & \multicolumn{2}{|}{ Indikator Keterampilan } & \multicolumn{2}{c}{ Rata-rata Skor } \\
\cline { 3 - 4 } & & Kelas Kontrol & Kelas Eksperimen \\
\hline 1. & Perencanaan/perancangan kegiatan & 3,80 & 3,80 \\
2. & Persiapan alat dan bahan & 7,25 & 7,47 \\
3. & Mengatur alat dan bahan & 17,79 & 18,47 \\
4. & Mengamati titik akhir titrasi & 3,57 & 3,33 \\
5. & Menyimpulkan hasil praktikum & 3,89 & 3,97 \\
6. & Perlakuan terhadap alat & 7,54 & 7,73 \\
7. & Kebersihan tempat kerja & 3,89 & 4,00 \\
\hline
\end{tabular}

Berdasarkan data pada Tabel 4 diperoleh bahwa peserta didik kelas eksperimen lebih terampil dalam melakukan praktikum karena terlebih dahulu telah melakukan 
praktikum di laboratorium virtual. Adanya laboratorium virtual disertai demonstrasi ini menjadikan peserta didik memiliki pandangan awal terhadap praktikum di laboratorium riil. Peserta didik juga dapat mengulang praktikum di laboratorium virtual hingga mereka paham. Di dalam virtual laboratory, peserta didik dapat mengetahui detail bahan-bahan yang digunakan untuk titrasi sehingga mereka lebih memahami proses titrasi. Hal ini sesuai dengan penelitian Tatli dan Ayas (2010) bahwa peserta didik dapat lebih fokus dalam melakukan praktikum di virtual laboratory tanpa mengkhawatirkan kondisi bahan dan alat yang digunakan. Pada kelas eksperimen juga disertai dengan demonstrasi penggunaan alat-alat laboratorium. Peserta didik lebih terampil ketika melaksanakan praktikum riil di laboratorium Kimia dan hasil belajar aspek keterampilan pada kelas eksperimen berada pada kategori sangat baik. Hasil ini sesuai dengan tujuan penambahan demonstrasi bahwa demonstrasi dilakukan untuk menambah pemahaman mereka mengenai penggunaan alat-alat titrasi yang baik dan benar. Pada kelas kontrol tidak berbeda jauh karena mereka telah mengamati demonstrasi yang dilakukan guru di depan kelas sebelum mereka melakukan praktikum riil di laboratorium Kimia. Hanya saja didalam demonstrasi tidak diketahui secara detail bahan-bahan yang digunakan untuk titrasi.

Berdasarkan data pada Tabel 4, terdapat 5 indikator dimana kelas eksperimen lebih tinggi daripada kelas kontrol, 1 indikator seimbang, dan 1 indikator kelas eksperimen lebih rendah daripada kelas kontrol. Kelima indikator dimana kelas eksperimen lebih tinggi yaitu persiapan alat dan bahan, mengatur alat dan bahan, menyimpulkan hasil praktikum, perlakuan terhadap alat dan kebersihan tempat kerja. Mayoritas indikator keterampilan pada kelas eksperimen memiliki skor yang lebih tinggi daripada kelas kontrol karena peserta didik telah melakukan praktikum terlebih dahulu di virtual laboratory sehingga dalam praktikum riil mereka lebih terampil dan mudah melakukannya.

Satu indikator yang seimbang yaitu perencanaan/perancangan kegiatan praktikum. Skor indikator ini seimbang antara kelas kontrol dan eksperimen karena keduanya menggunakan model pembelajaran yang sama yaitu POE. Model ini menuntun peserta didik untuk berlatih memprediksikan rancangan kegiatan praktikum sebelum mereka melakukan praktikum secara langsung sehingga kedua kelas telah terampil dalam membuat rancangan praktikum. Satu indikator dimana kelas eksperimen lebih rendah 
daripada kelas kontrol yaitu mengamati titik akhir titrasi. Hal ini dikarenakan pada virtual laboratory, jika larutan $\mathrm{NaOH}$ yang ditambahkan berlebihan maka warna larutan tetap pink, tidak berubah menjadi pink tua atau ungu, sehingga peserta didik kesulitan dalam menentukan titik akhir titrasi secara benar. Hal ini menyebabkan mereka kurang berhati-hati dalam meneteskan larutan $\mathrm{NaOH}$ ketika melakukan praktikum titrasi secara langsung di laboratorium Kimia.

Berdasarkan evaluasi hasil belajar aspek psikomotorik, kelas eksperimen lebih tinggi daripada kelas kontrol atau kelas yang menggunakan bantuan virtual laboratory disertai demonstrasi memiliki rata-rata hasil belajar aspek psikomotorik yang lebih tinggi daripada kelas tanpa virtual laboratory. Hasil ini sejalan dengan penelitian Nurrokhmah \& Sunarto (2013) dan penelitian Jaya (2012) bahwa Laboratorium virtual dapat meningkatkan kompetensi peserta didik dari segi keterampilan.

Data yang diperoleh berikutnya dalam penelitian ini yaitu skor keterampilan berpikir kritis. Keterampilan berpikir kritis diukur dengan instrumen tes pilihan ganda two tier melalui pretest dan posttest. Perbandingan kategori keterampilan berpikir kritis pretest dan posttest disajikan pada Tabel 5.

Tabel 5 Perbandingan Kategori Keterampilan Berpikir Kritis

\begin{tabular}{lccccccc}
\hline \multirow{2}{*}{ Kelas } & & \multicolumn{7}{c}{ Kategori } & Jumlah \\
\cline { 3 - 7 } & & $\begin{array}{c}\text { Sangat } \\
\text { Baik }\end{array}$ & Baik & Cukup & Kurang & $\begin{array}{c}\text { Sangat } \\
\text { Kurang }\end{array}$ & $\begin{array}{c}\text { Peserta } \\
\text { Didik }\end{array}$ \\
\hline \multirow{2}{*}{ Kontrol } & Pretest & 0 & 0 & 0 & 10 & 18 & 28 \\
& Posttest & 0 & 10 & 14 & 4 & 0 & 28 \\
& Pretest & 0 & 0 & 1 & 15 & 14 & 30 \\
& Posttest & 0 & 17 & 13 & 0 & 0 & 30 \\
\hline
\end{tabular}

Berdasarkan data pada Tabel 5 diperoleh bahwa terdapat perubahan skor KBK yang lebih baik dari pretest ke posttest. Skor KBK posttest kelas eksperimen lebih baik daripada kelas kontrol. Pada kelas eksperimen terdapat 17 peserta didik memenuhi kriteria baik dan 13 peserta didik memenuhi kriteria cukup. Pada kelas kontrol terdapat 10 peserta didik memenuhi kriteria baik, 14 peserta didik memenuhi kriteria cukup, dan 4 peserta didik memenuhi kriteria kurang.

Indikator KBK yang diukur ada 6 yaitu identifikasi masalah, sumber-sumber yang mendukung, analisis, fakta yang bertentangan, asumsi pribadi, dan simpulan. Rata-rata skor setiap indikator disajikan pada Tabel 6 . 
Tabel 6 Rata-rata Skor Indikator KBK

\begin{tabular}{llcccc}
\hline \multirow{2}{*}{ No. } & \multicolumn{1}{c}{ Indikator } & \multicolumn{4}{c}{ Rata-rata Skor } \\
\cline { 3 - 6 } & & \multicolumn{3}{c}{ Kelas Kontrol } & Kelas Eksperimen \\
\cline { 3 - 6 } & Pretest & Posttest & Pretest & Posttest \\
\hline 1. & Identifikasi Masalah & 2,86 & 8,46 & 2,97 & 8,31 \\
2. & Sumber-sumber yang mendukung & 6,43 & 18,93 & 7,90 & 19,91 \\
3. & Analisis & 3,46 & 8,32 & 4,00 & 8,16 \\
4. & Fakta yang Bertentangan & 0,25 & 1,29 & 0,47 & 0,94 \\
5. & Asumsi Pribadi & 1,46 & 1,57 & 2,03 & 2,50 \\
6. & Simpulan & 1,68 & 5,32 & 1,57 & 6,06 \\
\hline
\end{tabular}

Skor pretest dilakukan analisis uji kesamaan varians dan uji dua rata-rata (satu pihak) yang menghasilkan varians yang sama dan rata-rata nilai yang sama. Skor posttest dilakukan 4 analisis yaitu uji kesamaan varians, uji dua rata-rata (satu pihak), uji pengaruh antar variabel, dan penentuan koefisien determinasi.

Hasil uji kesamaan varians diperoleh nilai $\mathrm{F}$ hitung sebesar 1,97 dan $\mathrm{F}$ tabel sebesar 2,14. Nilai F hitung lebih kecil dari F tabel, hal ini menunjukkan bahwa skor KBK posttest kelompok kontrol dan eksperimen memiliki varians yang sama (Ho diterima) sehingga uji dua rata-rata (satu pihak) dilakukan dengan menggunakan rumus t. Hasil uji dua rata-rata (satu pihak) diperoleh nilai t hitung sebesar 2,28 dan nilai t tabel sebesar 1,67. Nilai t hitung lebih besar dari t tabel. Hasil tersebut menunjukkan bahwa rata-rata skor KBK posttest kelas eksperimen lebih besar dari kelas kontrol. Uji pengaruh antar variabel menghasilkan nilai rb sebesar 0,36 dan termasuk kategori rendah. Koefisien determinasi yang diperoleh yaitu 12,66\%. Jika dilihat rata-rata skor KBK posttest pada Tabel 6, indikator ke 1, 3, dan 4 lebih unggul kelas kontrol daripada kelas eksperimen.

Indikator KBK yang pertama yaitu identifikasi masalah. Identifikasi masalah yang dimaksudkan yaitu mengklarifikasi persoalan untuk didiskusikan. Pada aspek ini, skor kelas eksperimen lebih rendah daripada kelas kontrol. Indikator KBK yang pertama diwakili oleh 4 butir soal pilihan ganda two tier. Salah satu soal dari indikator ini yaitu peserta didik diminta untuk mengidentifikasikan penyebab terjadinya kesalahan pada titrasi asam-basa. Pada kelas kontrol yang menggunakan demonstrasi dapat lebih jelas dalam mengamati hal yang terjadi ketika ada kesalahan titrasi seperti warna larutan menjadi sangat pink, sedangkan hal tersebut tidak dapat diamati dengan jelas pada virtual laboratory. 
Indikator KBK yang kedua yaitu sumber-sumber yang mendukung. Sumbersumber yang mendukung yang dimaksudkan yaitu mengidentifikasi sumber informasi atau fakta yang digunakan untuk membangun alasan atau menarik kesimpulan. Pada aspek ini, skor kelas eksperimen lebih tinggi daripada kelas kontrol. Indikator KBK yang kedua diwakili oleh 7 butir soal pilihan ganda two tier. Salah satu soal dari indikator ini yaitu disediakan alat-alat laboratorium, peserta didik dapat mengelompokkan alat-alat yang digunakan untuk titrasi. Peserta didik mengidentifikasi alat-alat titrasi yang telah disediakan dalam soal kemudian menentukan alat apa saja yang digunakan untuk melakukan titrasi asam-basa. Software virtual laboratory dapat menjadikan peserta didik lebih fokus dalam melakukan proses titrasi sehingga peserta didik dapat dengan mudah mengetahui alat-alat apa saja yang digunakan untuk titrasi. Hasil ini sesuai dengan penelitian Tatli dan Ayas (2010) bahwa virtual laboratory dapat menjadikan peserta didik lebih fokus dalam melakukan praktikum.

Indikator KBK yang ketiga yaitu analisis. Analisis yang dimaksud yaitu menganalisis pernyataan atau fakta untuk membangun argumen atau kesimpulan. Pada aspek ini, skor kelas eksperimen lebih rendah daripada kelas kontrol. Indikator KBK yang ketiga diwakili oleh 5 butir soal pilihan ganda two tier. Salah satu soal dari indikator ini yaitu peserta didik dapat memperkirakan bentuk kurva titrasi. Virtual laboratory yang digunakan oleh kelas eksperimen tidak dapat membuat kurva titrasi secara otomatis, sehingga kurang membantu peserta didik dalam memperkirakan kurva titrasi yang terjadi dan harus dibuat secara manual.

Indikator KBK yang keempat yaitu fakta yang bertentangan. Maksud dari fakta yang bertentangan yaitu meninjau fakta, informasi, pendapat para ahli, dan atau metode yang bertentangan. Pada aspek ini, skor kelas kontrol lebih tinggi daripada kelas eksperimen. Indikator KBK yang keempat diwakili oleh 1 butir soal pilihan ganda two tier. Soal tersebut mengenai penyebab perubahan warna pada titrasi asam-basa. Salah satu kelemahan dari Virtual laboratory yaitu tidak dapat memberikan warna yang berbeda ketika titran yang diteteskan berlebih. Hal ini menyebabkan peserta didik kurang dapat mengetahui kapan titran yang diteteskan telah berlebih sehingga peserta didik tidak dapat memperhatikan atau mengidentifikasi informasi lain yang berkaitan dengan perubahan warna titrasi. Hasil ini sesuai dengan penelitian Tatli dan Ayas 
(2010) yang menyatakan bahwa tidak semua pihak dapat menggunakan informasi dalam Virtual laboratory secara efektif.

Indikator KBK yang kelima yaitu asumsi pribadi. Asumsi pribadi yang dimaksudkan yaitu mengakui prasangka atau asumsi perorangan. Pada aspek ini, skor kelas eksperimen lebih tinggi daripada kelas kontrol. Indikator KBK yang kelima diwakili oleh 1 butir soal pilihan ganda two tier. Soal tersebut yaitu peserta didik diminta menganalisis ion yang jumlahnya lebih dominan sebelum titrasi mencapai titik ekivalen. Software virtual laboratory menyajikan alat dan bahan titrasi secara lengkap, sehingga peserta didik dapat lebih berlogika atau memiliki pandangan mengenai ion-ion yang terlibat dalam proses titrasi. Hasil ini juga sesuai dengan penelitian Tüysüz (2010) dalam Tatli dan Ayas (2010) yang menyatakan bahwa virtual laboratory dapat membantu peserta didik lebih mudah dalam memahami konsep.

Indikator KBK yang keenam yaitu menjelaskan kesimpulan. Pada aspek ini, skor kelas eksperimen lebih tinggi daripada kelas kontrol. Indikator KBK yang keenam diwakili oleh 2 butir soal pilihan ganda two tier. Salah satu indikator soal tersebut yaitu peserta didik diminta untuk menghitung konsentrasi dari suatu zat dari hasil titrasi yang dilakukan. Software virtual laboratory mempermudah peserta didik untuk mengetahui informasi dari larutan yang digunakan untuk titrasi dan peserta didik telah terbiasa belajar menghitung konsentrasi suatu zat melalui soal yang diberikan guru saat praktikum menggunakan virtual laboratory, sehingga peserta didik lebih mudah dalam menjawab soal posttest yang diberikan. Hasil penelitian ini sesuai dengan penelitian Oloruntegbe dan Alam (2010) dalam Tatli dan Ayas (2010) yang menyatakan bahwa virtual laboratory dapat meningkatkan proses pembelajaran peserta didik.

Pada uji dua rata-rata (satu pihak) diperoleh bahwa skor KBK posttest kelas eksperimen lebih tinggi daripada kelas kontrol. Hal ini berarti keterampilan berpikir kritis kelas eksperimen lebih baik daripada kelas kontrol, atau dengan kata lain, kelas yang proses pembelajarannya berbantuan virtual laboratory memiliki keterampilan berpikir kritis yang lebih baik daripada kelas yang tidak berbantuan virtual laboratory. Nilai rb sebesar 0,36 dan koefisien determinasi sebesar 12,66\% menunjukkan bahwa virtual laboratory berkontribusi terhadap keterampilan berpikir kritis. Hal ini sejalan dengan penelitian Yusuf \& Widyaningsih (2017) yang menyatakan bahwa proses 
pembelajaran menggunakan media Laboratorium Virtual berpengaruh positif terhadap keterampilan berpikir kritis. Penelitian lain yang sejalan yaitu Sutarno, dkk (2018) yang menyatakan bahwa virtual laboratory dapat meningkatkan keterampilan berpikir kritis.

\section{SIMPULAN}

Berdasarkan hasil penelitian dapat disimpulkan bahwa terdapat perbedaan ratarata hasil belajar dan keterampilan berpikir kritis antara kelas eksperimen dan kelas kontrol pada pembelajaran POE berbantuan virtual laboratory; terdapat kontribusi virtual laboratory pada pembelajaran POE terhadap hasil belajar sebesar 16,99\%; dan terdapat kontribusi virtual laboratory pada pembelajaran POE terhadap keterampilan berpikir kritis sebesar 12,66\%. Saran dari penelitian ini yaitu bagi peneliti lain yang hendak memanfaatkan media virtual laboratory dapat menerapkan pada materi lain dan perlu adanya instrumen tambahan untuk mengukur keterampilan berpikir kritis. 


\section{DAFTAR PUSTAKA}

Argandi, R., K.S. Martini, \& A.N.C. Saputro. 2013. Pembelajaran Kimia dengan Metode Inquiry Terbimbing Dilengkapi Kegiatan Laboratorium Real dan Virtual Pada Pokok Bahasan Pemisahan Campuran. Jurnal Pendidikan Kimia (JPK), 2(2). ISSN 2337-9995.

Ayvaci, H.S. 2013. Investigating The Effectiveness of Predict-Observe-Explain Strategy on Teaching Photo Electricity Topic. Journal of Baltic Science Education, 12(5). ISSN: $1648-3898$.

Bakhtiar, Yusrizal, \& I. Khaldun. 2016. Penggunaan Model Pembelajaran Kooperatif Tipe STAD untuk Meningkatkan Motivasi dan Hasil Belajar Siswa pada Materi Titrasi Asam-Basa di Kelas XI SMA Negeri 6 Lhokseumawe. Jurnal Pendidikan Sains Indonesia. Vol.04. No. 02. Hlm: 202-215.

Erni, M., M. Napitupulu, \& J. Sakung. 2013. Pengaruh Model POE (Predict-ObserveExplain) Terhadap Hasil Belajar Kimia pada Kelas XI Materi Kelarutan dan Hasil Kali Kelarutan di SMA Negeri 4 Pasangkayu. Jurnal Akademi Kimia, 2(2): 62-67.

Fabian, K., K.J. Topping, \& I.G. Barron. 2016. Mobile Technology and Mathematics: Effects on Student's Attitudes, Engagement, and Achievement. J. Comput. Educ, 3(1): 77-104.

Harrison, T.G., Shallcross, D.E., Heslop,W.J., Eastman J.R., \& Baldwin, A.,J. (2009). Transferring Best Practice From Undergraduate Practical Teaching To Secondary Schools: The Dynamic Laboratory Manual, Acta Didactica Napocensia, 2,1,1-8.

Ikhsan, M. \& Afdal. 2016. Kajian Motivasi Belajar Siswa Dalam Pembelajaran Kimia Menggunakan Virtual Lab. Jurnal Pendas Mahakam, 1(1): 65-68.

Jaya, H. 2012. Pengembangan Laboratorium Virtual untuk Kegiatan Praktikum dan Memfasilitasi Pendidikan Karakter di SMK. Jurnal Pendidikan Vokasi, 2(1), 8190.

Matsun., W. Sunarno., \& M. Masykuri. 2016. Penggunaan Laboratorium Riil dan Virtuil pada Pembelajaran Fisika dengan Model Inkuiri Terbimbing Ditinjau dari Kemampuan Matematis dan Keterampilan Berpikir Kritis. Jurnal Pendidikan Fisika, 4(2), 137-152. p-ISSN: 2337-5973. e-ISSN: 2442-4838.

Mulyatun. 2013. Laboratorium Kimia Virtual: Alternatif Pembelajaran Kimia untuk Meningkatkan Hasil Belajar Mahasiswa Tadris Kimia IAIN Walisongo Semarang. Jurnal Inovasi Pendidikan Kimia, 7(1), 1031-1043.

Nurrokhmah I.E \& W. Sunarto. 2013. Pengaruh Penerapan Virtual Labs Berbasis Inkuiri Terhadap Hasil Belajar Kimia. Chemistry in Education, 2(1), 200-207. ISSN: 2252-6609. 
Oloruntegbe, K., O. \& Alam, G., M. (2010). Evaluation of 3D Environments and Virtual Realities in Science Teaching and Learning: The Need to Go Beyond Perception Referents, Scientific Research and Essays,5(9), 948-954.

Permana, N.A., A. Widyatmoko., \& M. Taufiq. 2016. Pengaruh Virtual Laboratory Berbasis Flash AnimationTerhadap Pemahaman Konsep dan Keterampilan Berpikir Kritis Peserta Didik Tema Optik Kelas VIII SMP. Unnes Science Education Journal, 5(3), 1354-1365.

Rosa, N.M. \& F.P. Nursa'adah. 2017. Kontribusi Laboratorium Kimia dan Sikap Siswa Terhadap Pemanfaatan Laboratorium Terhadap Keterampilan Berpikir Kritis dan Kreatif. Jurnal Formatif, 7(3), 198-206. ISSN: 2088-351X.

Srereekha, S., A. Raj. R., \& S. Sankar. 2016. Effect of Predict-Observe-Explain Strategy on Achievement in Chemistry of Secondary School Students. International Journal of Education \& Teaching Analytics, 1(1), 1-5.

Surbakti, D. Anggraini \& Supartono. 2016. Pengembangan Karakter Siswa Pada Pembelajaran Kimia Berbasis Teknologi Informasi Menggunakan Metode Diskusi. Jurnal Inovasi Pendidikan Kimia, 10(2), 1807 - 1816.

Sutarno., A. Setiawan., A. Suhandi., I. Kaniawati., \& D. Hamdani. 2018. Model Higher Order Thinking Virtual Laboratory: Model Praktikum Fisika Berbasis Keterampilan Berpikir Kritis dan Pemecahan Masalah Secara Kreatif. Jurnal Pendidikan Eksakta, 3(5), 189-193. ISSN 2528-3200.

Tatli, Z. \& A. Ayas. 2010. Virtual laboratory Applications in Chemistry Education. Procedia Social and Behavioral Sciences, 9:938-942.

Tüysüz, C. 2010. The Effect of the Virtual Lab. on Students' Achievement and Attitude in Chemistry, International Online Journal of Educational Sciences, 2, 1, 37-53.

Yusuf, I. \& S.W. Widyaningsih. 2017. Penerapan Laboratorium Virtual pada Mata Kuliah Praktikum Fisika terhadap Keterampilan Berpikir Kritis Mahasiswa Pendidikan Fisika Universitas Papua. Jurnal Sainsmat, 6(1), 75-81. ISSN 25795686 (Online). ISSN 2086-6755 (Cetak). 